\title{
Phytochemical Screening of Different Solvents Extracts of Flower of Capparis decidua (Forsk) Edgew
}

\author{
Bijal D. Patel ${ }^{1 *}$, Dr. Arun Kumar Mishra ${ }^{2}$ \\ 1 PhD Research Scholar, Department of Biotechnology, Mewar University, Chittorgarh, \\ Gangarar,Rajasthan-312901,India \\ ${ }^{2}$ Lokmani Memorial Degree College, Kadrabad Khurd, Seohara,Bijnor-246761,India \\ *Corresponding Author: bijalpatel85@gmail.com
}

\section{ABSTRACT :}

The present investigation was phytochemical screening of flower of Capparis decidua (Forsk.) Edgew. The flower was extracted by using different solvents such as Aqueous, Acetone, Methenol, Hexane and Chloroform. Capparis deciduas (Forsk.) Edgew, commonly known as Kair, belongs to the family Cappardaceae. The Flower buds are used for eaten to relieve stomach ache. The phytochemical analysis divulge presence of alkaloids, flavonoids, steroids, terpenoids, glycosides, saponins, phenols, tannins, proteins, amino acids, carbohydrates and reducing sugar in varying concentration. However, steroids, terpenoids and glycosides were found in all solvents extracts of flower. Alkaloids and Carbohydrates were found in aqueous, acetone and methanol extracts. Flavonoids and Amino acids were found in hexane extract. Phenol, Tannin, Protein and Amino acid were found in aqueous and methanol extracts. Reducing sugar also found in aqueous, methanol and chloroform extracts. Capparis decidua flower was used in ethno medicine, including treating stomach disorders and skin diseases, for both humans and animals. Phytochemical screening of medicinal plants is essential to find out and develop novel therapeutic agent.

Keywords: Capparis decidua, flower extracts, phytochemical screening

\section{I.INTRODUCTION}

Phyotochemical have been recognized as starting point for traditional herbal medicine (Lalitha .T.P. 2012).They are bioactive chemicals of plant origin.They are naturally synthesized in all parts of the plant body,bark,leaves,stem,root,flower,fruits,seeds etc (Tiwari P. 2011). All most $80 \%$ of the world's population relies on traditional medicines for primary health supervision,most of which require the use of plant extracts.In India almost $95 \%$ of the prescriptions were used in Unani,Ayurveda,Homeopathy and Siddha (Satyavati G.V. 1987).

Extraction is the separation of medicinally active portions of plant tissue using selective solvent through standard procedures. The extract thus obtained after standardization, may be used as medicinal agent as such in the form of solution or fluid extracts or further processed to be incorporated in any dosage from such as tablets and capsules. These products contains complex mixture of many medicinal plant metabolites, such as alkaloids, glycosides, terpenoids, flavanoids and lignans (Handa S.S. 2008).

Capparis decidua (Forsk.) Edgew, commonly known as Kair. Kair is a chiefly found in dry and arid regions growing wild in Rajasthan,Gujarat,Punjab and Western Ghats of India Flowers are pink in colour,red-veined,in small groups along the leafless shoots, in the axils of spines. Red conspicuous flower appear in March to April (Sushila .R. 2010).

The present investigate to study the phytochemical screening of the different solvents extract of Flower of Capparis decidua.

\section{II.EXPERIMENTAL WORK}

Plant Material: Plant material Flower of Capparis decidua (Forsk.) Edgew was obtain from desert area in Gujarat,India.

Processing of plant material: The flower were washed in running tap water several times for remove the dust particle and then dried under shade 2-3 weeks. The dried material was taken and ground using electric blender mixture to obtain a fine powder. The powder sample were stored in a clean glass bottle until needed for analysis.

Preparation of extracts: The dried and ground powder $10 \mathrm{gm}$ were successively extracted in $100 \mathrm{ml}$ with different solvents like Aqueous, Acetone, Methenol, Hexane and Chloroform for $24 \mathrm{hrs}$ stand at room temperature. Extracted sample was filtered with whatman No.1 filter paper. The filtrate extract was stored in refrigerator at $4^{0} \mathrm{C}$ until use. 
Phytochemical Screening: The flower extracts of Capparis decidua were analysed for the presence of alkaloids, flavonoids, steroids, terpenoids, glycosides, saponins, phenols, tannins, proteins, amino acids, carbohydrates and reducing sugar according to the common phytochemical methods described by Brain and Turner (1975).

\section{Test for Alkaloids}

A known quantity $3 \mathrm{ml}$ of the extract was taken and added to $1 \mathrm{ml}$ of dilute hydrochloric acid and boiled gently for 20 min, after boiling, it was cooled and filtered. The filtrate was subjected to Mayer's test. Filtrate was treated with 2 drops of Mayer's reagent were added. Formation of yellow colored precipitate indicated the presence of alkaloids.

\section{Test for Flavonoids}

Alkaline reagent test : A known quantity $4 \mathrm{ml}$ of the extract was treated with $10 \% \mathrm{NaOH}$ solution, formation of intense yellow colour indicates presence of flavonoid.

\section{Test for Steroids}

Salkowski Test : A known quantity $2 \mathrm{ml}$ of the test sample was extracted in the $2 \mathrm{ml}$ of chloroform and filtered. The filtrate was mixed with $2 \mathrm{ml}$ of conc. $\mathrm{H}_{2} \mathrm{SO}_{4}$ carefully so that the sulphuric acid formed a lower layer. A reddish-brown colour at the interphase indicated the presence of steroidal ring.

\section{Test for Terpenoids}

Chloroform test: The known quantity $3 \mathrm{ml}$ of extract was taken mix with $3 \mathrm{ml}$ of chloroform and add conc. $\mathrm{H}_{2} \mathrm{SO}_{4}$ carefully to form a layer and observed for presence of reddish brown colour.

\section{Test for Glycosides}

Keller-Killani Test: The known quantity $2 \mathrm{ml}$ of extract was treated with $2 \mathrm{ml}$ glacial acetic acid containing a drop of $\mathrm{Fecl}_{3}$. $\mathrm{A}$ brown colour ring indicates the presence of glycosides.

\section{Test for Saponins}

Foam test : The known quantity $2 \mathrm{ml}$ of extract was added $6 \mathrm{ml}$ of water in a test tube. The mixture was shaken vigorously and observed for the formation of persistent foam that confirms the presence of saponins.

\section{Test for Phenols}

Ferric chloride test: The known quantity $2 \mathrm{ml}$ of the extracts was treated with aqueous $5 \%$ ferric chloride and observed for formation of deep blue or black colour.

\section{Test for Tannins}

Braymer's test: The known quantity $2 \mathrm{ml}$ of the extracts was treated with $10 \%$ alcoholic ferric chloride solution and observed for formation of deep blue or greenish colour.

\section{Test for Proteins}

Xanthoproteic test: The known quantity $2 \mathrm{ml}$ of the extracts was treated with few drops of concentrated $\mathrm{HNO}_{3}$ formation of yellow colour indicates the presence of protein.

\section{Test for Amino acids}

Ninhydrin test: The known quantity $2 \mathrm{ml}$ of the extracts was treated with $2 \mathrm{ml}$ of ninhydrain solution and boil for few minutes, formation of blue or purple colour indicates the presence of amino acids.

\section{Test for Carbohydrates}

Molish's test : The known quantity $2 \mathrm{ml}$ of the extracts was treated with few drops of Molish's reagent and add $2 \mathrm{ml}$ of concentrate $\mathrm{H}_{2} \mathrm{SO}_{4}$ down the side of the test tube formation of violet ring at the junction indicates the presence of carbohydrates.

\section{Test for Reducing Sugars}

Fehling test: The known quantity $2 \mathrm{ml}$ of the extracts was hydrolyzed with dilute $\mathrm{HCl}$ and neutralized with alkali and heated with Fehling's solution A and B, formation of red ppt indicates the presence of reducing sugars.

\section{III.RESULTS AND DISCUSSION}

Results acquired for preliminary phytochemical screening in different solvents extracts of flower of Capparis decidua are 
presented in Table. 1

On the Twelve phytochemicals screened was found present in various solvents extracts. They are Alkaloids, Flavonoids, Steroids, Terpenoids, Glycosides, Saponins, Phenols, Tannins, Proteins, Amino Acids, Carbohydrates and Reducing Sugars. Steroids, Terpenoids, Glycosides and Carbohydrates were present in all solvents extracts.

Table 1. Results of phytochemical screening of Flower of Capparis decidua

\begin{tabular}{|c|c|c|c|c|c|}
\hline Phytochemicals & & Dif & it solvents & acts & \\
\hline & Aqueous & Acetone & Methanol & Hexane & Chloroform \\
\hline Alkaloids & + & + & ++ & - & - \\
\hline Flavonoids & - & - & - & + & - \\
\hline Steriods & ++ & + & +++ & + & + \\
\hline Terpenoids & +++ & + & +++ & + & + \\
\hline Glycosides & + & + & + & + & ++ \\
\hline Saponins & - & ++ & ++ & - & - \\
\hline Phenols & +++ & - & ++ & - & - \\
\hline Tannins & +++ & - & ++ & - & - \\
\hline Proteins & ++ & - & + & - & - \\
\hline Amino acids & +++ & - & +++ & + & - \\
\hline Carbohydrates & +++ & +++ & +++ & - & - \\
\hline Reducing Sugars & +++ & - & + & - & +++ \\
\hline
\end{tabular}

$$
\text { Key: }(+)=\text { present }(-)=\text { absent }
$$

Alkaloids,Steriods,Terpenoids,Glycosides,Phenols,Tannins,Proteins,Amino acids and Reducing sugars were present in Aqueous extract. Alkaloids,Steriods,Terpenoids,Glycosides,Saponins and Carbohydrates were present in Acetone extract. Alkaloids, Steriods, Terpenoids,Glycosidase, Saponins, Phenol, Tannins, Proteins, Amino acids, Carbohydrates and Reducing Sugar were present in Methanol extract. Flavanoids, Steroids, Terpenoids, Glycosides and Amino acid were present in Hexane extracts. Steroids, Terpenoids, Glycosides and Reducing sugar were found in Chloroform extract. The Glycosides are applicable in lowering blood pressure, treatment of congestive heart failure and cardiac arrhythmia (Nyarko A.A. 1990). Terpenoids are applicable in treatment of cough, asthma and hey fever. Steroids show the analgesic properties and responsible for central nervous system activities (Akindele A.J. 2007). Saponins have been extensively traditionally applicable as detergents and pesticides in inclusion to their industrial applications as foaming and surface active agents and also health benefits effects(Shi J.K.2004). The growth of many fungi, yeast ,bacteria and viruses was inhibited by Tannins(Chung K.T. 1998). Phenol acts as antioxidants (Han X.2005). 


\section{CONCLUSION AND FUTURE SCOPE}

Phytochemicals found present in Flower extracts of Capparis decidua their potential as source of principles that may supply novel drugs or medicines. Further studies are therefore suggested to ascertain their antibacterial, antifungal and antidiabetic activities.

\section{ACKNOWLEDGEMENT}

The authors are thankful to Department of Biotechnology, Mewar University, Chittorgarh, Gangarar,Rajasthan for providing the necessary facilities for the completion of the work.

\section{REFERENCES}

[1] Akindele, A.J.and Adeyemi,O.O, Anti-inflammatory activity of the aqueous leaf extracts of Byrsocarpus coccineus. Fitoterapia,78: pp. 25-28,2007.

[2] Brain K.R. and Tuner T.D, The practical evaluation of phytopharmaceuticals. Wright Scientectica Publishers, Bristol. pp 57-58, 1975.

[3] Chung, K.T, Wong,T.Y, Wei,C.L, Huang Y.W. and Lin, Y,Tannins and human health.A review, Criti. Rev. Food. Sci. Nutri. 6:pp.421-446,1998.

[4] Handa,S.S, Khanuja, S.P.S ,Longo, G and Rakesh,D.D, Extraction Technologies for Medicinal and Aromatic Plants. International centre for science and high technology, Trieste, pp.21-25, 2008.

[5] Han, X, Shen T, and Lou H., Dietary polyphenols and their biological significance. Int. J. Mol. Sci. 8(9):pp.950$988,2005$.

[6] Lalitha, T.P and Jayanthi,.P, “Asian J Plant Sci Res Vol. 2 Issue.2, pp 115-122, 2012.

[7] Nyarko, A.A and Addy, M.E, Effects of aqueous extract of Adeniacissampeloideson blood pressure and serum analyze of hypersensitive patients.Phytotherapy Res. 4(1): pp 25-28,1990.

[8] Satyavati, G.V, Gupta,A.K and Tandon, N "Medicinalplants of India". Indian council of Medicinal Research,New Delhi,India, Vol.2. 1987.

[9] Shi, J.K, Arunasalam, D,Yeung, Y, Kakuda, G, Mittal and Jiang, Y, Saponins from edible legumes. Chemistry, Processing and health benefits. J. Med. Food. 7: pp. 67-78, 2004.

[10] Sushila, R, Permender R, Dharmender R, Deepti R and Vikash K, Phytochemical and Pharmacological Potential of Kair ( Capparis decidua). 2 pp 10-17,2010.

[11] Tiwari, P, Kumar, B, Kaur, M, Kaur, G, and Kaur, H, "Phytochemical screening and extraction: a review," Internationale Pharmaceutica Sciencia, Vol. 1, Issue. 1, pp. 98-106, 2011. 